\title{
Terrorist SPEECH UNDER BILlS C-51 AND C-59 AND THE OTHMAN HAMDAN CASE: THE CONTINUED INCOHERENCE OF CANADA'S APPROACH
}

\author{
KENT ROACH*
}

\begin{abstract}
It is argued that neither the approach taken to terrorist speech in Bill C-51 nor Bill C-59 is satisfactory. A case study of the Othman Hamdan case, including his calls on the Internet for "lone wolves" "swiftly to activate," is featured, along with the use of immigration law after his acquittal for counselling murder and other crimes. Hamdan's acquittal suggests that the new Bill C-59 terrorist speech offence and take-down powers based on counselling terrorism offences without specifying a particular terrorism offence may not reach Hamdan's Internet postings. One coherent response would be to repeal terrorist speech offences while making greater use of court-ordered take-downs of speech on the Internet and programs to counter violent extremism. Another coherent response would be to criminalize the promotion and advocacy of terrorist activities (as opposed to terrorist offences in general in Bill C-51 or terrorism offences without identifying a specific terrorist offence in Bill C-59) and provide for defences designed to protect fundamental freedoms such as those under section 319(3) of the Criminal Code that apply to hate speech. Unfortunately, neither Bill C-51 nor Bill C-59 pursues either of these options. The result is that speech such as Hamdan's will continue to be subject to the vagaries of take-downs by social media companies and immigration law.
\end{abstract}

\section{TABLE OF CONTENTS}

I. INTRODUCTION . . . . . . . . . . . . . . . . . . . . . . . . . . . . . . . . . . . . . . . 204

A. OutLine ........................... 206

II. The Constitutional and Strategic Flaws of the Bill C-51

“ADVOCACY OF TERRORISM OFFENCES IN GENERAL” OFFENCE . . . . . 208

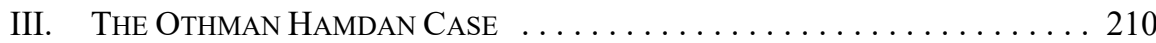

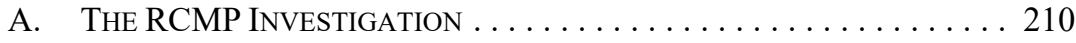

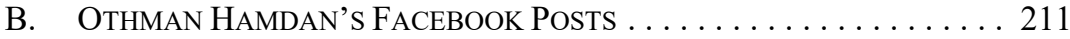

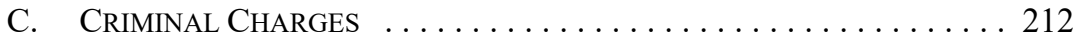

D. IMMIGRATION DETENTION AND DEPORTATION ATTEMPTS . . . . . 216

E. SuMMARY . . . . . . . . . . . . . . . . . . . . . . . . . . . . . . . 219

IV. The CONSTITUTIONAL AND STRATEGIC FlaWs OF

THE BILL C-59 “COUNSELLING TERRORISM OFFENCES WITHOUT

IDENTIFying A SPECIFIC TERRORISM OFFENCE” OFFENCE . . . . . . . . . 220

V. TOWARDS A DEFENSIBLE AND JUSTIFIED APPROACH

to REPEALING the TerRorist SPEECH OfFEnCE . . . . . . . . . . . . . 222

VI. TOWARDS A DEFENSIBLE AND JUSTIFIED APPROACH

TO A TERRORIST SPEECH OFFENCE . . . . . . . . . . . . . . . . . . 224

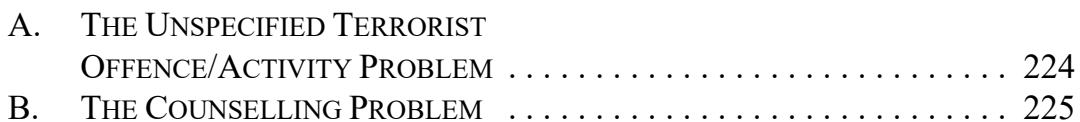

Professor of Law and Prichard-Wilson Chair in Law and Public Policy, University of Toronto, and Faculty, Centre for Transactional Legal Studies, London, United Kingdom, where an earlier version of this article was presented at a conference on Hate Speech in Times of Crisis. 


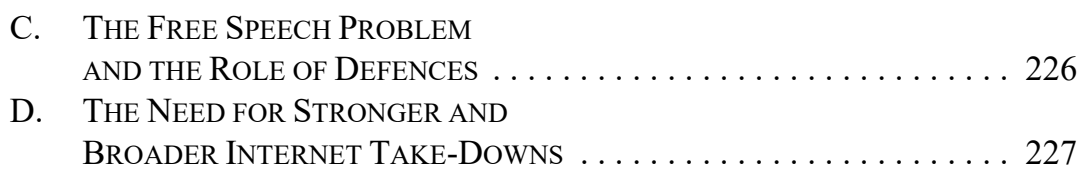

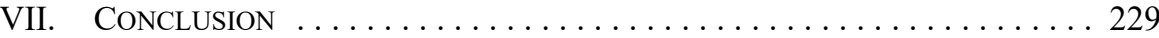

\section{INTRODUCTION}

The terrorism speech offence in Bill C-51 was only a small part of its massive and radical restructuring of national security legislation enacted in response to two terrorist attacks in October 2014. Nevertheless, it was in many respects emblematic of the Stephen Harper government's counterterrorism strategy. Prime Minister Harper argued that violent jihadism "is not a human right ... [but] an act of war," and his Attorney General Peter Mackay explained that the new speech offence encompassed those who actively encouraged unspecified actions "to do something bad against Canadians or our allies, or to do something to support extreme jihadism.",

The Conservative government responded to the 2014 acts of terrorism by a variety of hard measures, including giving CSIS a mandate to take threat reduction measures up to and including violating the Canadian Charter of Rights and Freedoms. ${ }^{3}$ It had little time for softer and sociological strategies of countering violent extremism (CVE) despite their endorsement in 2014 by the United Nations Security Council in Resolution $2178 .^{4}$ The Bill C-51 offence of advocating or promoting "terrorism offences in general" while knowing or being reckless as to whether any of terrorism offences would be committed as a result of the communication was primarily an expressive or symbolic offence meant to denounce extremism. ${ }^{5}$ Any use of the Bill C-51 speech offence would have attracted a challenge under the Charter. In some respects, that may have been the government's point.

During the debate, the Liberal Party took the equivocal position that while it would support Bill C-51, it would, if elected, amend it with special attention to respecting the Charter. After having produced a Green Paper on National Security that in many respects offered a bureaucratic defence of Bill C-51 that was not made when it was enacted, ${ }^{6}$ the Justin Trudeau government introduced Bill C-59 in June 2017 with it only finally being enacted in June 2019 before Parliament dissolved for the 2019 election.

1 Janyce McGregor \& Kady O’Malley, “Stephen Harper Makes His Case for New Powers to Combat Terrorism," CBC News (30 January 2015), online: <www.cbc.ca/news/politics/stephen-harper-makeshis-case-for-new-powers-to-combat-terror-1.2937602>.

2 Cited in Craig Forcese \& Kent Roach, False Security: The Radicalization of Canadian Anti-Terrorism (Toronto: Irwin Law, 2015) at 337 [Forcese \& Roach, False Security].

3 Part I of the Constitution Act, 1982, being Schedule B to the Canada Act 1982 (UK), 1982, c 11 [Charter].

$4 \quad$ Resolutions and Decisions of the Security Council, UNSCOR, 70th year, UN Doc S/INF/70 (2014) 211 at 215 .

$5 \quad$ Criminal Code, RSC 1985, c C-46, s 83.221, as amended by the Anti-terrorism Act, 2015, SC 2015, c 20, s 16 .

$6 \quad$ Government of Canada, Our Security, Our Rights: National Security Green Paper, 2016 (Ottawa: Her Majesty the Queen in Right of Canada, 2016). 
Bill C-59's revision of the speech offence was again a political focus point of the debates. ${ }^{7}$ For the Conservative opposition, the revised bill was a sign that the Trudeau government was soft on terrorism whereas for the government it was a sign of their respect for the Charter. For the NDP, the failure to repeal the speech offence in its entirety was a sign of the Liberals' "two-faced" approach "of saying one thing and doing the opposite." The Trudeau government's approach to terrorism has been characterized by an unwillingness to be placed at a political disadvantage by being depicted as soft on terrorism combined with a desire to be seen as complying with the Charter. ${ }^{9}$ As discussed in other articles in this issue, Bill C-59 retains CSIS's new ability to take steps to disrupt and reduce threats to national security and much of its broad information-sharing law. At the same time, the Trudeau government has shown more interest in CVE than the Harper government by creating the Canada Centre for Community Engagement and Prevention of Violence. ${ }^{10}$

The new terrorist speech offence in Bill C-59, no less than the old speech offence, is emblematic of the government's counterterrorism policy. On the one hand, it seeks to ensure compliance with the Charter by replacing the Bill C-51 wording of "promoting and advocating" with a narrower and more traditional reference to "counselling." This change was made despite the 2017 decision of $R$. v. Hamdan that interpreted counselling restrictively so as not to apply to Internet speech that praised the September 2014 terrorist attacks in Canada and called for more of them. ${ }^{11}$ The counselling requirement in Bill C-59 may mean that such speech will not be subject to criminal sanction or court-ordered deletion as terrorist propaganda under Bill C-59.

On the other hand, Bill C-59 stops short of repealing the terrorist speech provision. It replaces the provocatively broad, undefined, and vague reference to "terrorism offences in general" in Bill C-51 with the still undefined and vague concept of counselling "a terrorism offence without identifying a specific terrorism offence."12 Although designed to cover generic calls for terrorism of the type seen in Hamdan, the new offence in section 83.221 of the Criminal Code is no clearer than the old and controversial Bill C-51 formula of "terrorism offences in general." What is clearer is that the new Bill C-59 offence requires proof of counselling as was also required in Hamdan.

It is, of course, easy to criticize the counterterrorism laws and policies of governments. The more difficult question is what improvements can be made. Compliance with the Charter is a necessary step, but hardly a sufficient one. One possible approach not taken in either Bill C-51 or C-59 would be to model a terrorist speech offence on hate propaganda provisions in section 319 of the Criminal Code and the definition of terrorist activity in section 83.01(b) of the Criminal Code, both of which have been upheld as consistent with

\footnotetext{
$7 \quad$ The new Bill C-59 offence provides: "Every person who counsels another person to commit a terrorism offence without identifying a specific terrorism offence is guilty of an indictable offence and is liable to imprisonment for a term of not more than five years" (Criminal Code, s 83.221, as amended by the National Security Act, 2017, SC 2019, c 13, s 143).

$8 \quad$ "Bill C-59, an Act respecting national security matters," 2nd Reading, House of Commons Debates, 42 1 , vol 148 No 234 (20 November 2017) at 1315 (Alexandre Boulerice).

$9 \quad$ See for example its support of a Conservative motion suggesting that foreign terrorist fighters that returned to Canada should be prosecuted: House of Commons Debates, 42-1, vol 148 No 339 (22 October 2018) and House of Commons Debates, 42-1, vol 148 No 340 (23 October 2018).

10 "Canada Centre for Community Engagement and Prevention of Violence," online: Public Safety Canada $<$ www.publicsafety.gc.ca/cnt/bt/cc/index-en.aspx $>$.

2017 BCSC 1770 [Hamdan].

National Security Act, 2017, supra note 7.
} 
the Charter. ${ }^{13}$ The fact that a terrorist speech offence could be successfully defended under the Charter, however, does not establish that it should be enacted or that it will make a necessary contribution to counterterrorism policy. ${ }^{14}$ This is especially true with respect to speech-based terrorism offences, which will remain extremely difficult and risky types of prosecutions regardless of how any specific offence is defined.

I will suggest that there are two viable and Charter-compliant approaches to terroristrelated speech. The first would be to accept that while vile and objectionable, most of the speech praising terrorism is "terrorist babble" that should not be criminal. ${ }^{15}$ Instead we should rely on non-criminal instruments ranging from social media censorship to CVE intervention. The second alternative would be to criminalize and provide for state censorship of speech that advocates, promotes, or instructs the commission of a terrorist activity. Such a broad approach that goes beyond the concept of counselling should, however, be balanced by the same type of defences available in section 319(3) of the Criminal Code for wilful promotion of hate propaganda to ensure respect for freedom of expression and freedom of religion.

In the end, the choice between the decriminalization option and the option modelled on hate speech and terrorist activity provisions is a tough call. It could legitimately be based on political preferences as determined by the policy preferences of the elected federal government. Alas, Bill C-59, like Bill C-51 before it, fails to take either of these constitutionally compliant and democratically defensible approaches.

\section{A. Outline}

Part II will examine and criticize the "advocacy and promotion of terrorism offences in general" offence enacted in Bill C-51. It will suggest that the undefined reference to "terrorism offences in general" was vague and overbroad. Bill C-51 borrowed selectively from hate speech provisions, but failed to include its high mens rea requirement, its exclusion of private conversations, or the broad range of defences designed to protect freedom of expression and freedom of religion that the Supreme Court of Canada deemed critical to their justification as a reasonable limit on fundamental freedoms.

Part III will provide a case study of the Othman Hamdan case. Hamdan's Facebook postings praising acts of terrorism such as the 22 October 2014 attack on Parliament, pledging his support for Daesh, and calling for "lone wolves [to] activate all across \#USA" attracted the attention of Facebook and the RCMP. ${ }^{16}$ Facebook was fairly successful in taking down Hamdan's posts: it deleted most of Hamdan's 14 accounts. The RCMP was less successful. After two brief discussions with him, the RCMP charged Hamdan with counselling murder, assault causing bodily harm, mischief to property, and knowingly instructing the carrying-out of a terrorist activity under section 83.22 of the Criminal Code. Hamdan was acquitted of all counts by Justice Butler of the British Columbia Supreme Court

\footnotetext{
13 See $R v$ Keegstra, [1990] 3 SCR 697 [Keegstra]; $R v$ Khawaja, 2012 SCC 69 [Khawaja]. Kent Roach, "The Dangers of a Charter-Proof and Crime-Based Response to Terrorism" in Ronald J Daniels, Patrick Macklem \& Kent Roach, eds, The Security of Freedom: Essays on Canada's AntiTerrorism Bill (Toronto: University of Toronto Press, 2001).

15 Craig Forcese \& Kent Roach "Criminalizing Terrorist Babble: Canada's Dubious New Terrorist Speech Crime" (2015) 53:1 Alta L Rev 35 [Forcese \& Roach, "Terrorist Babble"]. Hamdan, supra note 11 at para 81 .
} 
in 2017, but he was kept in immigration detention. The Immigration and Refugee Protection Board ruled in 2018 that the same 85 Internet posts that were the basis of his criminal charges established that the Minister reasonably believed that Hamdan was a threat to the security of Canada. As a result, the Minister revoked Hamdan's refugee status and ordered him to be deported to Jordan, something that he continues to contest. The Hamdan case provides important information about the reality of terrorist-related speech, the difficulties of prosecuting it, and the dangers of relying on less restrained alternatives to prosecution.

Part IV will examine the constitutional and strategic infirmities of the approach now taken in Bill C-59 to criminalize the counselling of terrorism offences without identifying a specific terrorism offence. Drawing on the Hamdan case study, it will suggest that the new Bill C-59 offence may be underinclusive in only allowing material that counsels another person to be criminalized or subject to court-ordered deletion from the Internet. Bill C-59 does not solve the problem of responding to the type of unspecific and generic calls and threats of terrorism seen in Hamdan. At the same time, its attempt to respond to this issue is unclear and may provoke a Charter challenge.

The last two sections will outline two different but justifiable approaches to terrorist speech that differ from those taken in Bill C-51 and Bill C-59. Part V will examine the option of repealing the terrorism speech offence while investing more in CVE and ensuring takedowns of terrorist material on the Internet. This approach does not mean that all terroristrelated speech will be tolerated. Existing offences against counselling specific crimes, issuing threats, and engaging in hate propaganda would still apply.

An alternative discussed in Part VI would be to retain Bill C-51's commitment to criminalizing speech that promotes and advocates terrorism while adding defences that would allow the accused to establish defences of truth, good faith arguments about religion, and discussion of public interest matters borrowed from the hate propaganda provisions in the Criminal Code. To be sure, such an approach would violate sections 2 and 11(d) of the Charter, but there would be a good chance that such limits on rights could be justified as reasonable and proportionate under section 1 of the Charter. ${ }^{17}$

Under either approach, speech-based terrorism prosecutions would rightly remain difficult. This underlines the need for broader in rem remedies to allow court-ordered deletion of a broader range of terrorist propaganda from the Internet. Unfortunately, the deletion provisions in Bill C-59 have been reduced to only include material that actually counsels terrorism offences, without even the qualification of not necessarily identifying a specific terrorism offence. ${ }^{18}$

To be sure, any court-ordered deletion procedure will remain far from the front lines in an ongoing battle with terrorist propaganda that is primarily being waged by social media companies such as Facebook and Twitter. Indeed such private deletion efforts may be accelerated in light of the Christchurch call supported by Canada and many other democracies (but not the United States) and tech giants such as Facebook and Twitter. ${ }^{19}$ 
There is a need for greater study of how the tech giants now act as front-line censors and the degree to which they may be influenced by public regulation.

\title{
II. The Constitutional And Strategic \\ FLAWS OF THE BILL C-51 "ADVOCACY OF TERRORISM OFFENCES IN GENERAL" OFFENCE
}

In the immediate aftermath of the October 2014 terrorist acts, the Harper government expressed interest in criminalizing the praise or glorification of terrorism. These initial suggestions were inspired by sections 1 and 2 of the United Kingdom's Terrorism Act, $2006 .{ }^{20}$ Despite its initial interest in such broad offences, the Conservative government enacted a narrower speech-based crime in Bill C-51, which provided:

\begin{abstract}
Every person who, by communicating statements, knowingly advocates or promotes the commission of terrorism offences in general - other than an offence under this section - while knowing that any of those offences will be committed or being reckless as to whether any of those offences may be committed, as a result of such communication, is guilty of an indictable offence and is liable to imprisonment for a term of not more than five years. ${ }^{21}$
\end{abstract}

This offence was a Charter-inspired retreat from European-style offences of glorification or apologia of terrorism. The new offence required proof of subjective fault in the form that the accused "knowingly" advocate or promote and either know or be "reckless" as to whether a terrorist offence "may be committed" as a result of this speech. This was a lower form of fault than many of the other terrorism offences enacted in the 2001 Anti-Terrorism Act that required proof of the higher subjective requirement of a terrorist purpose. ${ }^{22}$

One model for the new Bill C-51 speech offence may have been offences against advocating genocide or underage sex. The problem, however, is that these crimes are fairly narrowly defined whereas the $\mathrm{C}-51$ offence was based on advocating or promoting "terrorism offences in general." This phrase was not defined in Bill C-51. It would seem to include, at the least, terrorism offences as defined in section 2 of the Criminal Code, which include a range of Criminal Code offences including those related to terrorism financing. This meant that speech such as "support terrorist group X" that the speaker was aware created the possibility that someone may send money to that group fell within the ambit of the Bill C-51 offence. This then suggested that the offence includes protected expression that is not excluded from section 2(b) of the Charter as either violence or threats of violence. ${ }^{23}$ Such a conclusion would require the state to then justify the broad offence as a reasonable limit under section 1 of the Charter.

The Bill C-51 offence in section 83.221 of the Criminal Code would be difficult to justify under section 1 of the Charter. Although courts would accept that deterring and denouncing

20 The United Kingdom has continued to regulate speech related to terrorism with extremely broad new offences relating to speech that supports a proscribed organization or that arouses a reasonable suspicion that a person is a member or supporter of a proscribed organization: Counter-Terrorism and Border Security Act 2019, (UK), ss 1-2. Criminal Code, supra note 5, s 83.221(1).

22 See for example the requirement in section 83.18 of the Criminal Code, ibid, that people "knowingly" participate in any activity of a terrorist group "for the purpose of enhancing" its ability to facilitate or carry out a terrorist activity.

$23 \quad$ Khawaja, supra note 13. 
terrorist violence was an important objective, it is not clear that prohibiting the advocacy or promotion of "terrorism offences in general" would be rationally connected to this objective. The government could argue for a broader objective such as disapproving of extremist speech, but the Supreme Court of Canada has so far rejected such attempts to inflate the purpose of counterterrorism provisions. ${ }^{24}$

There are a broad range of less rights-invasive options. For example, the wilful promotion of hatred offence that provided a model for section 83.221 of the Criminal Code exempts statements made in "private conversation" 25 and has various free speech, free religion, and public interest defences. ${ }^{26}$ All of these provisions could be examples of less rights-invasive ways to pursue the objective of Bill C-51's new terrorist propaganda offences and deletion procedures.

Finally, the overall balance achieved by Bill C-51 was in doubt given that it might include speech that was not directly related to terrorist violence. Moreover, the benefits of a prosecution with a maximum five-year sentence to preventing terrorism or stemming the tide of terrorist-related speech or terrorism were not clear. The adverse effects of the C-51 offence on freedom of expression, however, were quite clear, especially the potentially chilling effects of the undefined reference to "terrorism offences in general."

Why did the government select the undefined and provocatively vague concept of "terrorism offences in general"? One clue is found in the 2016 Green Paper issued by the Trudeau government that provided as an example of speech that might be targeted by the new offence a video statement by a person dressed in military clothing to her followers to "take direct action.... Do not wait for us to tell you what to do. From now on, you have permission to do whatever you want, do whatever is in your capability. Just act." ${ }^{27}$ The Green Paper elaborated that the Bill C-51 speech offence "extends the concept of counselling to cases where no specific terrorism offence is being counselled, but where it is evident nonetheless that terrorism offences are being counselled." ${ }^{28}$ It is far from clear, however, that such extortions to take "direct action" or "just act" necessarily were calling on listeners to commit any activity that would constitute any terrorist offence. Context matters. The direct action called for in the Green Paper example could be either a bombing or a protest. The choice to wear military clothing could be an implicit call to arms or a fashion choice. Any terrorist speech prosecution would be uncertain and context-dependent.

Events subsequent to the Green Paper and the introduction of Bill C-59 now provide concrete and public examples of the type of terrorist-related speech that the government in Bill C-51 was aiming to prohibit. It is important, especially in the national security field where commentators are only able to see partial and public evidence, to consider such new evidence in formulating policy. Unfortunately, there was little discussion of Hamdan as Bill C-59 was debated even though the case provided critical information about the nature of

Application under s 83.28 of the Criminal Code (Re), 2004 SCC 42.

Criminal Code, supra note 5, s 319(2).

Ibid, s 319(3).

Government of Canada, Our Security, Our Rights: National Security Green Paper, 2016 - Background Document (Ottawa: Her Majesty the Queen in Right of Canada, 2016) at 42.

Ibid. 
terrorist speech and the limits of the counselling requirement. ${ }^{29}$ Hamdan provides a concrete example of the concerns expressed by the Harper government when enacting Bill C-51 about unspecific calls to terrorism, as amplified by the Trudeau government's 2016 National Security Green Paper.

\section{The Othman Hamdan CaSe}

\section{A. THE RCMP INVESTIGATION}

Othman Hamdan came to Canada in 2002 from the United States and was granted refugee status in Canada in 2004. Hamdan eventually moved to the remote British Columbia town of Fort St. John, where he was not active or even known to the local Muslim community of about 100 persons until his arrest. ${ }^{30}$ Hamdan first came to RCMP attention during Project Savvy, a non-targeted examination of open media postings started after the Parliament Hill terrorist attack on 22 October 2014.

The RCMP found Hamdan's Facebook posts expressing admiration for the October 2014 terrorists and Daesh to be alarming. Hamdan was interviewed by two uniformed RCMP officers in the remote northern community of Fort St. John, British Columbia, on 19 November 2014. Little is known about this interview other than the two RCMP officers were in uniform and they did not make extensive notes. Two different RCMP officers interviewed Hamdan a second time on 1 April 2015, this time at a Tim Horton's where they bought him coffee and a muffin. ${ }^{31}$ In ruling that his statements to the police were voluntary, the trial judge observed that Hamdan was

a ready and willing conversationalist. He wanted to discuss his online activities and political views with the police. He was anxious to educate the police about the inaccurate reporting by the Western media of the conflict in Syria. He was keen to point out the errors of the Canadian and Western governments as well as the positive attributes of ISIS. He was happy to discuss the Facebook posts. ${ }^{32}$

By February 2015, the RCMP had started a more focused investigation of Hamdan called Project Scollop. Extensive resources appear to have been devoted with production orders under the Criminal Code and a Mutual Legal Assistance Treaty (MLAT) request being made to Facebook in the United States. Unfortunately, the RCMP used non-forensic software that did not allow them to capture and preserve the full Facebook posts. The August 2015 American reply to Canada's April 2015 MLAT request was also unable to replicate Hamdan's full posts. Despite the captured posts being "truncated and incomplete," the trial judge admitted 85 Facebook posts as the best evidence available. ${ }^{33} \mathrm{He}$ also found that the missing material from the Internet was not lost through unacceptable negligence in violation

29 A search of the words "Othman Hamdan" on the Parliamentary website revealed no discussion of the case as of 10 June 2019. The omnibus nature of the bill may also have inhibited debate, and I confess my own brief to the House of Commons committee studying the bill did not include a discussion of Hamdan because I had not completed my research on Hamdan.

30 Kim Bolan, "Terror Suspect Operated a Construction Business; Othman Hamdan, Charged with Counselling Murder for ISIL, Had Few Connections in Fort St. John, Sun Investigation Finds," The Vancouver Sun (14 July 2015) A6. Hamdan has claimed at various times he has converted to Christianity.

$R v$ Hamdan, 2017 BCSC 61 at paras 4-7.

Ibid at para 58 .

$R v$ Hamdan, 2017 BCSC 676 at para 78. 
of section 7 of the Charter. ${ }^{34}$ The case, however, does reveal some of the challenges of prosecuting speech made on the dynamic Internet.

Hamdan was arrested in Fort St. John, British Columbia, on 10 July 2015 by between 10 and 12 RCMP officers, including members of an Integrated National Security Team. The investigation was led by different officers than those who had interviewed him in November 2014 and April 2015. Hamdan was charged with counselling murder, counselling assault causing bodily harm, and counselling mischief to property for the benefit of a terrorist group under sections 464 and 83.2 of the Criminal Code and instructing a terrorist activity under section 83.22. As the trial judge noted in holding that a brief delay in informing Hamdan of the charges he faced was warranted, such charges were "very serious and out of the ordinary." $" 35$

Hamdan faced a maximum penalty of life imprisonment for the most serious charge he faced: counselling murder. This was far more than the maximum penalty of five years' imprisonment he would have faced under the new advocacy and promotion of "terrorism offences in general" offence in Bill C-51 that was proclaimed in force shortly after Hamdan's arrest. This meant that the new Bill C-51 offence could not be applied retroactively to posts he made before its enactment. It also illustrates how the Criminal Code treats counselling as a more serious offence that is tied to the offence being counselled or incited as opposed to offences based purely on speech that promotes and advocates but does not actively encourage people to commit a particular crime.

\section{B. Othman Hamdan's Facebook Posts}

The RCMP knew that Hamdan's Facebook postings over a period of ten months from 22 September 2014 to 9 July 2015 “included references to 'lone wolf' attacks, the use of explosives and firearms, and to potential Canadian 'targets' for terrorist attacks." ${ }^{36}$ The posts also commented on matters of politics and religion and matters of whether acts in Syria and Iraq constituted terrorism.

Hamdan's Facebook posts included salutes to "lone wolves" who committed terrorist attacks, including the October 2014 terrorists in Canada. ${ }^{37} \mathrm{He}$ similarly praised terrorists when he wrote: "Gun shots fired at NSA building ... lone wolves we salute you" and "[t]hree shot outside an American Islam phobic competition ... lone wolves we salute you." ${ }^{38}$

Hamdan also seemed to indicate his willingness to engage in acts of terrorism. He wrote: "I am here for the support of the mujuhadeen ... terrorizing of the enemy .. until God grants me martyrdom .. with a car with buttons." 39 He also posted "Islamic state .. I am one of them," "Dear muslim brother and sister ... the Islamic State is the solution to all our

\footnotetext{
$34 \quad$ Ibid at para 108. The trial judge warned, however, that "if the police procedures do not improve, subsequent decisions may find the police action to be unreasonable" (ibid at para 113). $R v$ Hamdan, 2017 BCSC 467 at para 24.

Ibid.

These posts included references to a "Muslim brother is martyred after killing Canadian solider," "stay here and bring the fight to their towns" and "[s]econd attack in as many days - you can thank Harper and his support of sectarian militias in Iraq" all made on 22 October 2014 with a subsequent description of one of the attackers as "the real hero" (see Hamdan, supra note 11, Schedule A, Posts 9-13, 18).

$38 \quad$ Ibid, Schedule A, Posts 43, 59.

Ibid, Schedule A, Post 37.
} 
problems .. we muslims will support it and establish the caliphate state," and "when I migrate I will go surely to ISIS." 40

Hamdan not only praised acts of terrorism and indicated his desire to engage in acts of terrorism. His posts included statements closer to incitement or counselling terrorism such as "[m]y Muslim brother. Be a terrorist ... Scaring the enemies of God"; "let's stay here and bring the fight to their towns!"; and "our advice to supporters in the \#US ... carry your actions there ... swiftly lone wolves activate all across \#USA." ${ }^{41}$

Hamdan also provided information that would be useful to those prepared to commit acts of terrorism in Canada and abroad. He posted observations about possible sites for terrorist attacks in Canada, noting that they were not well-guarded and that Muslims could purchase firearms and explosive licences for under $\$ 200$. He posted detailed instructions about weapons, targets, forms of clothing to be worn, and transportation to be used to facilitate terrorist acts of violence in Egypt.

Hamdan's posts were made from 14 different Facebook accounts with many of the posts, re-posts, and accounts being deleted by Facebook. Unfortunately the judgments in the case provide little information about how Facebook became alerted to the posts and how it decided to delete the posts and the accounts that Hamdan used. ${ }^{42}$

Facebook's actions in this case are important, but less than transparent. In any event, Hamdan saw Facebook as his main nemesis. He testified that Facebook was "biased against Islam" and warned Facebook "the safety of your employees has already been determined by your actions!!"43 This threat against Facebook, like Hamdan's reposting of calls to "lone wolves" to "swiftly ... activate," were lacking in specifics.

As will be seen below, only one of Hamdan's 85 posts - the one calling for lone wolves swiftly to activate - was held to constitute the actus reus of counselling. In contrast his calls for Daesh-inspired violence and threatened violence against Facebook were subsequently held by the Immigration and Refugee Protection Board to be evidence that Hamdan as a noncitizen previously granted refugee status was a threat to the security of Canada.

\section{Criminal Charges}

Criminal charges in respect to counselling murder, assault, and mischief were laid against Hamdan. Section 22(3) of the Criminal Code defines counselling as procuring, soliciting, or inciting. The Supreme Court has in R. v. Hamilton interpreted counselling as "deliberate encouragement or active inducement of the commission of a criminal offence.",44

The trial judge stressed the difficulty of assessing the true meaning of Hamdan's social media posts. Even with the assistance of competing expert evidence, "the depth and complexity of the political and religious issues touched on by Mr. Hamdan's posts make it

Ibid, Schedule A, Posts 48, 53, 83 .

Ibid at para 81 .

Ibid at para 4 .

Ibid at para 23 and Schedule A, Post 57.

2005 SCC 47 at para 29 [Hamilton]. 
difficult to discern the clear meaning of many of the posts." 45 The nature of social media was relevant to the trial judge's decision to acquit. He stressed that the 85 key posts offered as evidence by the Crown were "small segments from a series of social media dialogues taking place over 10 months on 14 different Facebook accounts ... it is not logical or reasonable to selectively choose from such a large body of comments over many months and assert that they should be read together to infer active inducement." ${ }^{26}$ For example, the trial judge held that three posts describing two unguarded sites in Canada and explaining that Muslims could purchase a licence for firearms or explosives for less than $\$ 200$ offered in relating to the counselling mischief to property charge should not be interpreted in light of the other posts that indicated a support for and even encouragement of terrorism. Justice Butler concluded that these three informational posts did not actively induce the commission of mischief to property and thus did not amount to even proof of the actus reus of counselling. ${ }^{47}$ The judge seemed to ask whether each post taken on its own terms satisfied the definition of counselling.

Justice Butler also held that "repugnant" posts that praised or glorified terrorist acts, including saluting the September 2014 terrorist attackers, did not amount to counselling because they did not include

\begin{abstract}
active inducement or encouragement for a reader to go and commit similar acts. There is a significant difference between a message that says, "the lone wolf attacks in Canada are happening because of wrongheaded government policies" and one that incites or induces a reader to "seek martyrdom by committing lone wolf terrorist acts similar to those of Mr. Rouleau or Mr. Zehaf-Bibeau". Mr. Hamdan did the former, not the latter. The former is an expression of a political point of view; the latter is the act of counselling an offence. ${ }^{48}$
\end{abstract}

Counselling does not include praise of past acts of terrorism.

Posts that did not even amount to the actus reus of counselling murder or assault included a cartoon created by Hamdan that "suggests that if the USA is arresting Muslims who want to travel to Syria to join ISIS, then jihadists will say '... let's stay here and bring the fight to their towns!" 49 This expression seems to come closer to counselling than a cartoon that the European Court of Human Rights held was reasonably criminalized that stated that Hamas dreamed of destroying the World Trade Centre, but bin Laden and Al Qaeda did it. ${ }^{50}$ As will be seen, the Immigration and Refugee Protection Board was also unwilling to interpret Hamdan's expression of support for terrorism as evidence that he was a threat to the security of Canada under immigration law. This demonstrates a stronger Canadian commitment to freedom of expression than seen in Europe. This may continue to place a fundamental restraint on the degree to which Canada will criminalize terrorist speech. At the same time, the decision-maker will make a difference. The Immigration Board was more willing to

Hamdan, supra note 11 at para 102 .

Ibid at paras 76,78 .

Ibid at para 75 .

Ibid at paras 107-108.

Ibid at para 81 .

Affaire Leroy c France, No 36109/03 (2 October 2008). Note that B'Nai Brith suggested in its brief on Bill C-59 that Canada should borrow from the Council of Europe and criminalize the glorification of terrorism (The League for Human Rights of Bnai Brith Canada, On Bill C-59: Combatting Incitement to Terrorism, by David Matas (B'nai Brith Canada, 2018), online: <www.ourcommons.ca/Content/ Committee/421/SECU/Brief/BR9684919/br-external/BnaiBrithCanada-e.pdf $>$ ). 
interpret Hamdan's expressions in a more holistic manner than Justice Butler who, in his decision to acquit Hamdan, examined each of his 85 different posts separately. One suspects a criminal jury might also have taken a more holistic approach.

Justice Butler held that posts where Hamdan appeared to indicate his intent to engage in acts of terrorism did not amount to counselling others to commit such acts. He elaborated:

There is a significant difference between saying, "I am prepared to kill the enemy" and telling others to "go out and kill the enemy". The former is a statement of one's personal views and intent. While it may indirectly encourage the commission of an offence, it is not direct encouragement or active inducement. The offence of counselling is limited to direct encouragement. ${ }^{51}$

This holding reveals some of the potential differences between counselling-based offences, including the one in Bill C-59 and the Bill C-51 promotion and advocacy offence. It is possible that a person such as Hamdan who expresses his or her intentions to engage in terrorism could be found to have wilfully or knowingly promoted or advocated terrorism.

Justice Butler found only one of 85 posts to constitute the actus reus or prohibited act of counselling. It was Post 40, a re-posting of a Daesh tweet that "our advice to supporters in the \#US ... carry your actions there ... swiftly lone wolves activate all across the \#USA." Even Mr. Hamdan recognized in questioning by the RCMP, “[t]hat's probably the only incriminating post you could have on me.... And it's — it's not even my words but that's ... the only one that I see that's really bad.... Because it says lone wolves activate., ${ }^{, 5}$

At the same time, Justice Butler expressed some reservations about his conclusion that Post 40 amounted to counselling by noting that "the Crown was unable to show not only the intended recipients, possible targets, methods or location of the counselled terrorist attacks but also could not show that "the offence was not committed." 54 The unspecified nature of the general incitement for "lone wolves swiftly to activate" also helps explain some of the desire in Bill C-51 to provide for incitement of "terrorism offences in general" or in Bill C-59 for the counselling of terrorism offences without the incitement of a specific terrorism offence. It will be suggested below, however, that neither Bill C-51 nor C-59 have satisfactorily dealt with this tricky problem.

Justice Butler did not resolve his reservations about whether an unspecified call for "lone wolves swiftly to activate" amounted to counselling because he had a reasonable doubt about Hamdan's mens rea. In reaching this conclusion, he took a holistic approach that gave weight to Hamdan's political views, which included beliefs "that are contrary to ISIS dogma" and that supported Hamdan's "contention that his intent in administering the Facebook pages and profiles was to highlight injustice, speak truth to power and generate discussion rather than to further the goals of ISIS or encourage criminal terrorist activity." ${ }^{55}$ The judge's approach demonstrates the asymmetry of a liberal criminal law that strives to give the accused the

Hamdan, supra note 11 at para 120 .

Ibid at para 81 .

Ibid at para 123 .

Ibid at para 124.

Ibid at paras 165-66. 
benefit of a reasonable doubt. It suggests that any terrorist speech prosecution, especially for speech on the Internet, will be difficult to sustain.

The Crown decided not to appeal Hamdan's acquittal given the decision to continue to hold him in immigration detention, but one arguable error of law that Justice Butler may have made was his failure to find clearly that there was a reasonable doubt that Hamdan had a "conscious disregard of the substantial and unjustified risk inherent in the counselling" in the lone wolves activate post. ${ }^{56}$ Justice Butler stressed the "high standard" of mens rea for counselling. ${ }^{57}$ This is generally appropriate for inchoate offences, but discounts the Supreme Court's controversial 2005 decision to expand the traditional mens rea for counselling to include not only intent that the offence counselled be committed by others, but "conscious disregard of the substantial and unjustified risk inherent in the counselling." 58 Two leading criminal law texts have interpreted this latter standard as the equivalent of recklessness, which is the lowest form of subjective mens rea, as well as one that is used in Bill C-51. ${ }^{59}$

Justice Butler's conclusion that there was a reasonable doubt that Hamdan had the mens rea required for counselling seems more consistent with Justice Charron's strong dissent in Hamilton, which stressed that in order to protect freedom of expression, that nothing less than proof of the accused's intent that others would commit the offence counselled would be sufficient. In my view, this is the best interpretation of counselling as an inchoate offence that applies to expression. Nevertheless, it seems to disregard the decision of the majority of the Supreme Court in Hamilton to also include knowledge of a substantial and unjustified risk as a new, lower, and alternative form of mens rea for counselling.

In the end, Hamdan's acquittal raises as many questions as it answers. To be sure, it makes clear that the expression of support or praise for terrorism and the expression of a personal willingness to engage in terrorism or participate in the activities of a terrorist group will not constitute even the actus reus of counselling. This provides support for the decision in Bill C-51 to criminalize the broader category of promotion and advocacy. At the same time, Justice Butler correctly indicated that a broader approach to counselling would raise freedom of expression issues. ${ }^{60}$ The acquittal also does not resolve the issue of how far the Supreme Court has, in Hamilton, expanded the mens rea of counselling or whether the counselling of an unspecified type of terrorism will constitute the prohibited act of counselling.

\footnotetext{
$56 \quad$ Hamilton, supra note 44 at para 29.

Hamdan, supra note 11 at para 153 .

See for example Justice Moldaver's decision in $R v$ Janeteas, 2003 CanLII 57385 (Ont CA), cited by Justice Charron in her dissent in Hamilton, supra note 44 at para 82.

59 Don Stuart, Canadian Criminal Law: A Treatise, 7th ed (Toronto: Carswell, 2014) at 746; Morris Manning \& Peter Sankoff, Manning, Mewett \& Sankoff: Criminal Law, 5th ed (Markham: LexisNexis, $2015)$ at 7.109. For a contrary view that Hamilton requires more "than a reckless awareness of the possibility that an offence would be committed," see Kent Roach, Criminal Law, 7th ed (Toronto: Irwin Law, 2018) at 163.

60 Hamdan, supra note 11 at paras $41-42$.
} 


\section{IMMIGRATION DETENTION AND DEPORTATION ATTEMPTS}

Hamdan was acquitted on 22 September 2017. He had been detained and denied bail since his arrest on 10 July 2015. ${ }^{61}$ This reaffirms how bail is a critical step in terrorism prosecutions and one that often results in prolonged pre-trial detention even for those who may eventually be acquitted of terrorism charges. ${ }^{62}$

A person such as Hamdan found not guilty of all counts could reasonably expect to be released from custody that day. Yet in another indication of how liberal norms have been challenged by counterterrorism even in established democracies, Hamdan was immediately transferred to the custody of the Canadian Border Service Agency on the day of his acquittal. Immigration authorities attempted to justify this "heads you lose, tails I win" approach by arguing that immigration inadmissibility proceedings carried a lower burden of proof and had different standards of liability focused on threats to security of Canada. ${ }^{63}$ These were true statements, but they failed to justify the functional form of double jeopardy that Hamdan faced after his acquittal. ${ }^{64}$

Hamdan was denied bail under section 3(1)(h) of the Immigration and Refugee Protection $A c t^{65}$ on public safety grounds with the adjudicator concluding "anyone who actively promotes and calls on people to engage in terrorist activity is engaging in behaviour and conduct that puts the Canadian public in danger, regardless of if that conduct meets the standard necessary to obtain a criminal conviction." ${ }^{66}$ The adjudicator also concluded that he was satisfied that Hamdan "will continue to be active in the online community by posting your own material and reposting other material that celebrates and encourages acts of terrorism and violence in instances where you believe that such acts are justified." ${ }^{67}$ If Hamdan had been granted bail before either his criminal or immigration proceedings, it is likely that he would have been subject to requirements to stay off the Internet and other restrictions. $^{68}$ Whether it is granted or denied, bail remains a powerful tool of counterterrorism.

61 William Stodalka, "Terror Suspect Denied Bail," Alaska Highway News (4 August 2015) A3.

62 Kent Roach, "Be Careful What You Wish For? Terrorism Prosecutions in Post 9/11 Canada" (2014) 40:1 Queen's LJ 99 at 105-13 (examining other cases of extensive pre-trial detention and acquittal or stays of proceedings on terrorism-related charges). Kim Bolan, "Acquitted ISIS Supporter Fights to Stay in Canada," The Province (27 September 2017) A4.

64 Similarly peace bond bail-type restrictions appear to have been imposed on John Nuttall and Amanda Korody and were only abandoned after the entrapment-based stay of their terrorism charges was affirmed on appeal ("Crown Drops Bid for Terrorism Peace Bonds on Couple Entrapped in B.C. Legislature Plot,” CBC News (2 January 2019), online: <www.cbc.ca/news/canada/british-columbia/ crown-drops-bid-for-terrorism-peace-bonds-on-couple-entrapped-in-b-c-legislature-plot-1.4963849>).

65 SC 2001, c 27.

66 Cited in Geordon Omand, "Acquitted Man Remains in Detention," The Globe and Mail (6 October 2017) S2. It is not clear whether bail should have been denied on the basis of Hamdan being a flight risk. Although he had lived in several places since coming to North America as an electrical engineering student in 1999, he had lived in Fort St. John since 2011 (Hamdan, supra note 11 at paras 15-20).

67 Cited in Kim Bolan, "Islamic State Supporter Ordered Detained by Immigration Board," The Vancouver Sun (6 October 2017) A1.

68 An interesting question is whether Hamdan could have been subject to bail requirements to engage with those providing counselling or working with programs to counter violent extremism. In Canada (Attorney General) v Driver, 2016 MBPC 3 at para 52, the judge held that imposing a counselling requirement as part of a peace bond was an unjustified violation of section 2 of the Charter because it imposed "ideological programming" affecting "subjective belief systems upon the subject." This decision by a provincial court was, however, not appealed. 
Hamdan argued that "I was found innocent from all of these false accusations but I'm still being incarcerated" and that as a result he was suffering from post-traumatic stress disorder. ${ }^{69}$ An RCMP threat assessment expressed concerns that Hamdan might be more dangerous than at the time of his 2015 arrest because of his sense of being victimized by the investigation and various legal proceedings, ${ }^{70}$ something that was also affirmed in the Board Decision holding him to be a threat to the security of Canada. ${ }^{71}$

The Board considered not only the 85 Facebook posts used in the criminal trial, but a thumb drive with beheading videos that a cellmate obtained from Hamdan and cell graffiti of a Daesh flag that he apparently created. ${ }^{72}$ There was also evidence from an in-custody inmate that Hamdan had threatened to blow up the RCMP headquarters in Surrey, British Columbia. ${ }^{73}$ This raises the question of whether criminal proceedings and detention may in some cases be counterproductive with respect to those who hold extremist beliefs that support terrorism. The use of an in-custody informant also underlines how the immigration proceedings were similar to criminal proceedings and like them, vulnerable to miscarriages of justice. ${ }^{74}$ An alternative approach would have been to engage in some form of CVE program that would have provided continuity and counselling for Hamdan. To be sure, the RCMP interviewed him twice before he was arrested, but this was done by four different officers and with the threat of law enforcement likely hanging over the interviews. ${ }^{75}$

The inadmissibility hearing before the Immigration and Refugee Board featured much of the same evidence that had been used in the criminal trial. The Board accepted much of the testimony about the meaning of Hamdan's posts and concluded that the testimony a defence expert had provided about "the many forms of jihad and the concept of the idealized Islamic State ... was nuance more relevant at the criminal trial where Mr. Hamdan had only to raise a reasonable doubt regarding the meaning and intention of his posts. Here it has been only necessary to draw conclusions about the meaning of posts at the reasonable grounds to believe standard." ${ }^{, 76}$ Hamdan's testimony that many of his references to the Islamic State referred to an idealized version of it may have contributed to the reasonable doubt that the criminal trial judge had about his intent, but they did not undermine the Immigration Board's conclusion that the Minister had reasonable grounds to believe that Hamdan was a threat to

\footnotetext{
69 Camille Bains, "Man Facing Deportation from Canada Says Terror Accusations Left Him Traumatized," The Canadian Press (22 May 2018).

70 Kim Bolan, "Supporter of ISIL Threated to Bomb RCMP HQ, Board Hears," The Vancouver Sun (3 October 2017) A8 [Bolan, "Supporter of ISIL"].

71 Canada (Minister of Public Safety and Emergency Preparedness) v Hamdan (18 October 2018), B700771 at para 171, online: Immigration and Refugee Board of Canada $<$ www.scribd.com/document/ 391688003/Hamdan-B7-00771-Admissibility-Hearing-Decision-18-10-2018> [Board Decision], stating that

Mr. Hamdan is considerably aggrieved by the criminal and immigration processes that have resulted in his incarceration since 2015 that he considers to be without justification ... I believe that the Minister has adequately established that this risk of Mr. Hamdan engaging in violence in the future adds to the finding that in relation to his Facebook activity he is a danger to the security of Canada.

72 Camille Bains, "Facebook Posts Were Reply to Propaganda Against Islamic State: Migrant," The Canadian Press (23 May 2018); Board Decision, ibid at paras 149-57.

Bolan, "Supporter of ISIL," supra note 70.

See generally Kent Roach \& Gary Trotter, "Miscarriages of Justice in the War Against Terror" (2005) 109:4 Penn St L Rev 967.

75 For additional critiques of giving the RCMP the lead role in CVE programs, see Forcese \& Roach, False Security, supra note 2 at 472-89.

Board Decision, supra note 71 at para 162.
} 
the security of Canada: a standard that is lower than even the civil standard of a balance of probabilities. ${ }^{77}$

Hamdan was found by the Board to be inadmissible to Canada as a "security threat" under section 34(1)(d) of the Immigration and Refugee Protection Act, defined by the Supreme Court as a serious threat "grounded on objectively reasonable suspicion based on evidence" and involving harm that "must be substantial rather than negligible." ${ }^{, 78}$ Despite equality-based arguments from his lawyer that "dangerous speech" that "would be lawful for a Canadian citizen to engage in" should not be used to justify the deportation of a non-citizen, ${ }^{79}$ the Board stressed that Hamdan had no qualified right to stay in Canada and that the IRPA was designed to prioritize security.

The Immigration Board, like Justice Butler, found that praise or glorification of terrorism was protected by freedom of expression. It broke Hamdan's posts into four categories: (1) those that demonstrated support for Daesh, (2) those that "praise or glorify" acts of terrorism, (3) those that advocate violence in the form of terrorism or that constitute threats of violence not protected by freedom of expression, and (4) those that threatened Facebook employees. ${ }^{80}$ It held that the first two categories were protected as freedom of expression and would not be sufficient grounds for the Minister to conclude that Hamdan was a threat to the security of Canada ${ }^{81}$ For example, references to the October 2014 terrorists in Canada as martyrs and heroes and to "[a] pressure cooker is followed by another one.... Salute to the cooks" in response to terrorist acts in the US were interpreted as praise or glorification of terrorism that were not sufficient to justify a decision that Hamdan was a threat to the security of Canada. ${ }^{82}$

The Board distinguished support and praise of terrorism from statements that advocate "violence in the form of terrorism" or that constitute "threats of violence" not protected by freedom of expression. ${ }^{83}$ Statements held by the Board to constitute threats to Facebook employees included "[d]o you think IS is not going to get to FB offices soon ... the safety of your employees !! has already been determined." 84 The Board also held that it was not relevant that Hamdan was not charged with making threats in his posts ${ }^{85}$ and that

[w] hether or not Mr. Hamdan had the personal ability or temperament to attack the offices of Facebook these posts threaten violence and encourage it. He admitted as much when he suggested that there is some small percentage of individuals that may be willing to conduct a Charlie Hebdo style attack on Facebook's offices. The use of the occasional happy-face emoticon does not moderate that threat. ${ }^{86}$

The Board also found that Hamdan was a danger to the security of Canada to the extent that he "advocates violence ... in support of the Islamic State" ${ }^{" 87}$ by identifying crucial

\footnotetext{
77 Board Decision, ibid at para 10, applying Mugesera $v$ Canada (Minister of Citizenship and Immigration), $2005 \mathrm{SCC} 40$ at paras 114-15 [Mugesera].

Board Decision, ibid at para 19, citing Suresh v Canada (Minister of Citizenship and Immigration), 2002 SCC 1 at para 90.

Bolan, "Supporter of ISIL," supra note 70

Board Decision, supra note 71 at para 47.

Ibid at paras 165-66.

Ibid at paras 85,99 .

Ibid at paras $165-66$.

Ibid at paras 106-107.

Ibid at para 114 .

Ibid at para 113 .

Ibid at para 165 .
} 
infrastructure in Canada as targets for terrorist attacks and by posting "a grotesque, 'how-to' guide to the slaughter of people who are not followers of Islam, for no other reason [than] that they are not followers of Islam." ${ }^{\text {" }}$ These conclusions were reached even though Justice Butler had reasonable doubts about the latter re-posting of an ISIS document because the RCMP had failed to capture the full post. Board Member Tessler noted that while Hamdan's Internet support of ISIS was "different than supplying money and weapons it is nonetheless a substantial form of support that endangers Canadians." ${ }^{, 99}$ This part of the Board's decision seems to come closer to applying the broader concept of promotion and advocacy found in the Bill C-51 offence than the more limited concept of counselling applied in Hamdan's criminal acquittal and subsequently used in the new Bill C-59 offence.

Hamdan has continued to resist deportation to Jordan. He has argued that he will be persecuted if returned, something that is not implausible given that a number of his posts included information about Daesh's rewards for the killing of Jordanian pilots and even the names of such pilots. This underlines the limits of using immigration law as anti-terrorism law where the ultimate remedy of deportation may implicate Canada in torture or other forms of mistreatment. Even if Hamdan is eventually deported, Canada will simply have exported its security threat. Hamdan also is claiming that he has converted to Christianity, a religion that he had embraced for almost more than ten years previously. ${ }^{90}$ Various judicial review proceedings are ongoing. Consistent with Canada's prior use of immigration law as antiterrorism law in the security certificate cases, Hamdan's deportation will be contested, uncertain, and controversial.

\section{E. SUMMARY}

This case study of the ongoing Othman Hamdan saga provides valuable context for better understanding the challenges and wisdom of criminalizing speech related to terrorism. Unfortunately, it does not appear to have figured in the Parliamentary debate on Bill C-59. The technological challenges of capturing the full content and context of speech, including re-postings on the Internet are great. The failure of the RCMP to capture Hamdan's full posts and conclusions that some of the most critical posts were re-posting the words of others influenced his acquittal. They seemed to play much less a role in the immigration proceedings that found him to be a threat to the security of Canada. The very different standards of proof used in the criminal and immigration proceedings also help explain the differing results. They raise serious issues about the fairness of the latter especially when applied to the drastic sanction of withdrawing refugee status and deporting Hamdan to Jordan.

Despite these differences, both proceedings similarly concluded that expression of support and praise for acts of terrorism was within the bounds of freedom of expression. This suggests a certain consensus about core freedom of expression values and that an expanded offence that prohibited glorification of terrorism would violate freedom of expression and be difficult to justify under section 1 of the Charter. The Immigration Board found that the majority of Hamdan's posts that expressed support for Daesh and its acts of terrorism were 
protected by freedom of expression and it was only his threats of violence against Facebook and his advocacy of violent terrorism that were not protected under section 2(b).

The Hamdan case study also illustrates that the public responses of criminal investigations and immigration proceedings lagged behind Facebook's private response in taking down much of the offensive material that Hamdan posted. ${ }^{91}$ Hamdan's initial sense of grievance and threats were directed at Facebook. During his continued detention since his July 2015 arrest, however, Hamdan has apparently developed a sense of grievance against the Canadian state and policing and immigration officials for their actions.

Reasonable people can reach different conclusions after examining the public albeit partial record of Othman Hamdan's speech. The large amount of investigative and judicial resources devoted to the case, combined with the failure to capture the full context of his social media postings, his acquittal, and the problematic immigration response, could lead one to conclude that criminalizing terrorist-related speech is not worth it. The decriminalization option might also be backed by greater resources to countering violent extremism. That said, the two visits by four different RCMP officers to discuss Hamdan's postings before his arrests did not change his behaviour though it is possible that trained civilians might have had greater success, especially if they had been able to consistently build a relationship and rapport with Hamdan.

Another reasonable response to the Hamdan case study is that it supports some form of a terrorist speech offence separate from a counselling-based offence. Justice Butler's judgment clearly indicates that praise for terrorism or indication of a personal willingness to engage in terrorism is not counselling. It also suggests that the incitement of unspecific crimes captured by the reference in Post 40 to "lone wolves activate" may present problems for a counselling offence. In the next section, it will be suggested that while both Bill C-51 and Bill C-59 have attempted to remedy the problem of advocacy of unspecified acts of violence, it is not clear that either has succeeded.

\section{The Constitutional and Strategic Flaws OF THE BILL C-59 “COUNSELLING TERRORISM OFFENCES Without IDENTIFYING A SPECIFIC TerRorism OFFEnCE” OFFEnCE}

At first reading, Bill C-59 proposed to replace the Bill C-51 offence of promoting or advocating terrorism offences in general with a simple reference to counselling "another person to commit a terrorism offence - other than an offence under this section." 92 The Conservatives raised this change from Bill C-51 as their prime objection to Bill C-59, arguing that the new offence would require specific persons to be counselled and that under it "terrorists will be free to spread all kinds of propaganda using social media, without any fear of being arrested or prosecuted.... This proposal is absurd, because it protects criminals and those who want to engage in violence." 93

91 On the pre-eminent role of tech giants and how neo-liberal governments concerned with post-9/11 terrorist threats have generally given them free reign to govern the Internet for the own advantage, see Shoshana Zuboff, The Age of Surveillance Capitalism: The Fight for a Human Future at the New Frontier of Power (New York: PublicAffairs, 2019).

92 Bill C-59, An Act respecting national security matters, 1st Sess, 42nd Parl, 2017, cl 143 (first reading 20 June 2017).

93 "Bill C-59, An Act respecting national security matters," supra note 8 at 1220 (Pierre Paul-Hus). 
The government responded to these criticisms by amending Bill C-59 to provide that "every person who counsels another person to commit a terrorism offence without identifying a specific terrorism offence" would be guilty of the speech offence under section 83.221 of the Criminal Code and subject to a maximum sentence of five years' imprisonment. $^{94}$

Department of Justice officials explained in committee that this amendment would allow the section 464 counselling offence as used in the Hamdan case to carry a higher punishment when a specific terrorism offence was incited, but that section 83.221 would apply when no specific terrorism offence was counselled. They also opined that there was no fundamental difference between counselling and promotion and advocacy, but that counselling was simply used as a more familiar term. Others, including the Canadian Bar Association, disagreed and argued that the amended counselling offence only replicated the existing section 464 offence..$^{95}$ Concerns were also raised by opposition Members of Parliament on the committee that they did not have advance notice of the proposed government amendment, one that was introduced at 9:00 p.m. on 25 April 2018. They requested an adjournment, but this request was rejected. The government's amendment was passed in the House committee that night. ${ }^{96}$ Despite the two years between introduction and the eventual enactment of the omnibus Bill C-59, there never seemed to be enough time to thoroughly explore or debate its complexities. $^{97}$

Terrorism offences are defined in section 2 of the Criminal Code. They include specific financing, participation, facilitation, and instruction offences in sections 83.02-83.04 and 83.18-83.28 of the Criminal Code, but also any indictable offence committed for the benefit of, at the direction of, or in association with a terrorist group and any indictable offence that also constitutes terrorism. Moreover, terrorism offences also include conspiracies, attempts, counselling, and being an accessory after the fact. Unlike the definition of terrorist activities under section 83.01(b), however, the definition of terrorism offences does not include "threats" to commit terrorism offences that do not amount to counselling. Thus, Hamdan's statements, including his threats against Facebook, would likely not be covered under the new Bill C-59 offence. This may be a good thing, but it is not clear that it is one that is intended by a government that rightly or wrongly decided to retain a terrorist speech offence.

It is not clear that the Bill C-59 formulation of counselling another person to commit a terrorism offence without identifying a specific terrorism offence actually cures the problem that it was meant to address of responding to generalized calls to violence of the type made by Hamdan. There is a danger that the new offence will create interpretative complexities that may make the offence unworkable. To be sure, there is a broad array of terrorism

$94 \quad$ Bill C-59, An Act respecting national security matters, 1st Sess, 42nd Parl, 2018, cl 143 (as passed by the House of Commons 19 June 2018).

95 Canadian Bar Association, "Bill C-59 - National Security Act, 2017" (Ottawa: Canadian Bar Association, 2018), online: <www.ourcommons.ca/Content/Committee/421/SECU/Brief/BR9621870/ br-external/CanadianBarAssociation-e.pdf $>$. Similar arguments were made by the Canadian Civil Liberties Association and the International Civil Liberties Monitoring Group in their briefs.

96 House of Commons, Standing Committee on Public Safety and National Security, Evidence, 42-1, No 108 (25 April 2018).

On the limits of Parliamentary expertise and time in debating matters of anti-terrorism laws, see Kent Roach "The Role and Capacities of Courts and Legislatures in Reviewing Canada's Anti-Terrorism Law" (2008) 24 Windsor Rev Legal Soc Issues 5. 
offences listed under section 2 of the Criminal Code, but there may still have to be proof of the counselling of one such terrorism offence.

Justice Butler alluded to potential problems because Hamdan did not specify what crimes should be committed by which activated lone wolves. Even if the prosecutor can overcome all of these hurdles in proving that an accused counselled "another person to commit a terrorism offence without identifying a specific terrorism offence," there are still the problems of establishing mens rea. Although Hamilton expands the mens rea of counselling beyond an intent that the offences counselled be committed, the expansion to include knowledge of an unjustified risk that the offence counselled would be committed did not make a difference in the Hamdan case. ${ }^{98}$ How the fault requirements would be applied to repostings on social media is unclear, and it may be relatively easy to conclude that there is almost always a reasonable doubt about an accused's actual intent in re-posting the words of another.

If, contrary to the above analysis, courts do not require that some (but not any specific) terrorism offence be counselled, it is difficult to see how the Bill C-59 offence infringes freedom of expression less than the Bill C-51 formulation of "terrorism offences in general." In both cases, the object of what the accused is counselling is not any terrorism offence defined in section 2 of the Criminal Code, but some new, undefined, and vague species of general or non-specific terrorism offence. The use of such a vague and undefined concept, especially in a speech offence, challenges basic concepts of legality, fair notice, and the rule of law. To be sure, the Supreme Court has not accepted that the need for codified crimes as a principle of fundamental justice under section 7 of the Charter, ${ }^{99}$ but there is a world of difference between accepting a common law crime of contempt of court and a crime based on a generic but non-codified concept of terrorism offences, especially when all the accused may have done is to engage in speech.

In the end, the new Bill C-59 offence of counselling a terrorism offence without counselling a specific offence seems to be incoherent. By employing counselling, it may simply replicate the existing counselling offences that were not proven in the Hamdan case. On the other hand, if the new Bill C-59 counselling offence is not redundant, it may be no less broad, unclear, and problematic than the Bill C-51 offence of promoting and advocating "terrorism offences in general." Parliament has not really improved the terrorist speech offence. It will be suggested below that there were two different but sounder options that it could have taken.

\section{TOWARDS A DEFENSIBLE AND JUSTIFIED APPROACH TO REPEALING THE TERRORIST SPEECH OFFENCE}

One better option would have been simply to repeal the broad Bill C-51 offence of promotion and advocacy of terrorism offences in general. Repeal can be supported on both practical and normative grounds. Practically, the criminalization of radicalized boasting about terrorism may send such speech underground only to give such speech undeserved

98 For other cases that suggest that Hamilton may not have dramatically expanded counselling offences, see $R v$ Jeffers, 2012 ONCA 1; St-Jacques c R, 2012 QCCA 1482.

United Nurses of Alberta $v$ Alberta (Attorney General), [1992] 1 SCR 901. 
public attention when it resurfaces and is prosecuted. ${ }^{100}$ To be sure, the Hamdan case did not receive a great deal of publicity, but it did affirm that those who are prosecuted for terrorist speech are unlikely to "mellow" because of the experience. ${ }^{101}$ Indeed, the Immigration Board accepted RCMP assessments that Hamdan presents a greater risk than when he was first arrested in 2015. ${ }^{102}$

Normatively, it is a mistake to equate speech praising terrorism or indicating a willingness to engage in terrorism with terrorism. Both Justice Butler and the Immigration Board rightly refused to focus on Hamdan's praise of terrorism. They condemned praise of terrorism as distasteful and odious, but held that it was not criminal or even evidence of a security threat. Such conclusions do not mean that speech is never criminal or that repeal of section 83.221 of the Criminal Code would decriminalize all terrorist speech.

Many of the terrorism offences enacted after 2001 could apply to speech done while participating with a larger terrorist group or speech that instructs persons to carry out a terrorist activity or other actions for a terrorist group. That said, it should be acknowledged that the Crown conceded that the instructing terrorist activity charge against Hamdan should be dismissed if it was unable to establish the counselling charges. Moreover, Justice Butler suggested in his brief examination of the instruction offence under section 83.22 that it would require proof of the actus reus of active and deliberate inducement and a high mens rea similar to the counselling offences. ${ }^{103}$ It is not, however, clear that the instruction offence should necessarily be interpreted as a species of counselling.

The Supreme Court has stated that statutory inchoate offences such as the instruction offence in section 83.22 have different purposes from traditional inchoate forms of liability such as counselling. As such, the statutory offences are not subject to the common-law-based restrictions on criminalizing remote risks. ${ }^{104}$ To be sure, section 83.22 requires that the accused knowingly instructs, but it lacks the purpose requirement found in the section 83.18 participation offence, perhaps in recognition of the low value of speech that instructs people how to commit a terrorist activity. This casts some doubt on Justice Butler's conclusion that section 83.22 as a distinct statutory inchoate offence has the same high mens rea standard that the Supreme Court held in Khawaja would apply to section $83.18 .^{105}$ It is also notable that Justice Butler's brief discussion of the instructing offence did not discuss the broad interpretative section 83.22(2), which makes clear that instruction can occur without the accused instructing particular persons or knowing their identity.

Another criminal offence that may have been applicable to Hamdan's threats against Facebook are offences relating to threatening persons with bodily harm or death. ${ }^{106}$ One of the advantages of such prosecutions is that they focus on the risk of specific acts of violence

\footnotetext{
$100 \quad$ Forcese \& Roach, "Terrorist Babble," supra note 15 at 57. Ibid at 58 .

Board Decision, supra note 71 at para 171.

Hamdan, supra note 11 at paras 192-93.

$104 \quad R v$ Legare, 2009 SCC 56 distinguishing $R v$ Déry, 2006 SCC 53, which prohibits the combination of forms of inchoate liability such as attempts and counselling.

105 See Hamdan, supra note 11 at para 193.

106 Criminal Code, supra note 5, s 264.1. It is not necessary to prove that the accused intended to carry out such threats and the threats need not be directed at a specific person so long as they are directed at an ascertained group of people ( $R v$ McRae, 2013 SCC 68). Like the Bill C-51 or C-59 offences, such threats when prosecuted by indictment are subject to a maximum penalty of five years' imprisonment.
} 
- murder, bodily harm, property damage — and avoid the definitional conundrums in proving that what was threatened constituted "terrorism offences in general," "a terrorism offence without specifying a specific terrorism offence," or even a "terrorist activity." The repeal of the Bill C-51 speech offence would not have meant that anything goes with respect to speech associated with terrorism.

\section{TOWARDS A DEFENSIBLE AND JUSTIFIED APPROACH TO A TERRORIST SPEECH OFFENCE}

It is possible to view the Hamdan case as support for a specific speech-based offence. The RCMP may have concluded that it did not have sufficient resources in Fort St. John to make either continued engagement or surveillance of Hamdan sustainable. They in consultation with the integrated national security team in Vancouver and likely headquarters in Ottawa concluded that an arrest was necessary when Hamdan continued to post objectionable content after two meetings with RCMP officers. Even though Facebook seemed to be able to delete many of Hamdan's posts, Hamdan continued to take evasive action. In any event, take-downs of his posts would not address any risk that Hamdan might act on his extremist views. To be sure, the available research suggests that there is not a direct conveyer belt from radical and extreme opinions to actual participation in terrorism. ${ }^{107}$ Nevertheless, the criminal and immigration responses to Hamdan's speech suggest that authorities were not prepared to run the risk of allowing Hamdan to remain free. Both Hamdan's case and debates about terrorist speech offences ultimately involve discussions about how much risk a free and democratic society is willing to tolerate and the best way to manage such risks.

The new Bill C-59 counselling-based offence may well not apply to Hamdan's speech with respect to its expression of active support for terrorist groups, praise of terrorist acts, and urging of other supporters to activate in non-specific ways. In short, a broader offence that retains Bill C-51's focus on promotion and advocacy of some general form of terrorism may be necessary to capture speech such as Hamdan's.

\section{A. The UnSPECIFIED TERRORIST OfFEnCE/ACTIVITy Problem}

It is far from clear that either the Bill C-51 reference to "terrorism offences in general" or the Bill C-59 reference to "terrorism offences without specifying a particular terrorism offence" adequately deals with the problem, revealed by the Hamdan calls for lone wolves to activate, of capturing advocacy or incitement of unspecified forms of terrorism. Both phrases are vague and undefined. Courts may interpret both by reference to terrorism offences as defined in section 2 of the Criminal Code. This may make both phrases potentially underinclusive in cases where the calls for "lone wolves to activate" cannot be related to particular terrorist offences or other indictable offences committed in support of or association with a terrorist group.

A better approach may have been for Parliament to criminalize not advocacy or counselling of terrorism offences (in general or without a specific terrorist offence) but

107 Clark McCauley \& Sophia Moskalenko "Toward a Profile of Lone Wolf Terrorists: What Moves an Individual from Radical Opinion to Radical Action” (2014) 26:1 Terrorism \& Political Violence 69. 
terrorist activities as defined in section 83.01 of the Criminal Code. This would require the Crown to prove that the speaker was calling for one of the generic forms of terrorist activity outlined in that provision. Some of Hamdan's speech might fall into this category because it was arguably clear that he was calling for people to act for political or religious causes to intimidate a population or force governments to act in a way that cause death or bodily harm, even if it was not clear exactly how these results would be achieved.

A requirement of promotion or advocacy of terrorist activities would exclude some actions that would be included in the definition of terrorism offences such as terrorism financing offences and other indictable offences committed for the benefit of or in association with a terrorist group that do not endanger life. Minister of Public Safety Ralph Goodale opposed a Senate amendment to add a reference to terrorist activity to section 83.221 on the basis that it was underinclusive because it would not capture counselling of terrorism offences that involved leaving Canada to participate in foreign terrorist activities. ${ }^{108}$ The Minister was correct to point that out, but he neglected to examine the option of charging a person with counselling the commission of terrorist offences that are not otherwise included in the definition of terrorist activities. In other words, even if section 83.221 was restrained by the definition of terrorist activities or even if it was repealed, a person could still be charged with counselling the commission of terrorism financing or travel offences that would not otherwise fall within the definition of terrorist activities.

The use of the phrase "terrorist activities" in a speech offence would protect freedom of expression by, for example, excluding speech that called for people to give money to finance the non-violent activities of terrorist groups. A focus on terrorist activities would also send a message that focused on denouncing violence and other activity that endangers life. Speech advocating the commission of terrorism offences that themselves do not constitute terrorist activities should be dealt with through separate prosecutions of counselling those criminal offences.

\section{B. The Counselling Problem}

The Hamdan case study illustrates that praise for acts of terrorism and indication of a personal willingness to engage in terrorism do not fall within counselling. Consistent with Supreme Court jurisprudence, the trial judge in Hamdan interpreted counselling to require active inducement or advocacy as opposed to mere description of an offence. ${ }^{109}$

In order to apply to some of Hamdan's speech, it may be necessary to retain Bill C-51's broader reference to promotion or advocacy. In Keegstra, the Supreme Court interpreted "promotion" to include "active support or instigation" or "to foment or stir up." "Although the Supreme Court stressed that this requires more than "simple encouragement or advancement," it does seem broader than counselling, especially in relation to active attempts to support or stir up. ${ }^{111}$ In R. v. Sharpe, the Supreme Court interpreted "advocate" to include expression that, when "viewed objectively," "sends the message" that the prohibited act, in

108 House of Commons Debates, 42-1, vol 148 No 429 (7 June 2019), a point accepted by the government leader in the Debates of the Senate, 42-1, vol 150 No 301 (12 June 2019).

Hamilton, supra note 44 at para 15 ; Mugesera, supra note 77 at para 64 .

Supra note 13 at 776 .

Ibid at 777. 
that case sex with underage children, should be pursued. ${ }^{112}$ Hamdan's speech seemed at least in part designed to send the message that violent acts of terrorism should be pursued.

Although the courts will exclude simple description of prohibited acts from the ambit of counselling, promotion, and advocacy alike, promotion and advocacy provide a broader prohibited act that includes active support, fomentation, and objectively viewed messages that the prohibited act should be pursued. The use of the broader concepts of promotion and advocacy mat be necessary to capture any of Hamdan's speech. At the same time, such a broader criminal act would require additional protections for freedom of expression that were not provided in Bill C-51.

\section{The Free Speech Problem AND THE ROLE OF DEFENCES}

The use of the definition of terrorist activity in section 83.01(b) of the Criminal Code in a speech offence as opposed to reference to terrorism offences would include at least one internal protection for fundamental freedoms. Section 83.01(1.1) excludes from that definition "the expression of a political, religious or ideological thought, belief or opinion ... unless it constitutes an act or omission that satisfies the criteria of that paragraph."113

Someone like Hamdan could argue that all of his speech was covered by such an exemption, but the exemption would not apply to speech that either counselled or threatened to commit an act or omission that would qualify as a terrorist activity. Thus, threats that Hamdan made towards Facebook and about acts of violent terrorism would arguably be included in a terrorist-activity-based speech offence, especially given that the definition of terrorist activity includes specified acts or acts and omissions "in or outside Canada." "114 In this respect, it is significant that Hamdan's clearest calls for violence related to the United States and the Middle East and not Canada.

Relying simply on the definition of terrorist activity might, however, not provide enough protection for freedom of speech. One issue would be what fault level would be applied to such speech. Section 83.01(b)(ii) requires that a person act intentionally. This high subjective fault level would presumably also apply to the references in the section to counselling and threatening, which would be the ones directly applicable in the speech context. In Keegstra, however, the majority of the Supreme Court stressed the importance of the even more onerous subjective fault requirement of "wilful" in order to limit the restriction of freedom of expression. The wilfulness fault element requires the Crown to prove that the accused has the conscious purpose of promoting the prohibited act or knows that it is virtually certain to result. ${ }^{115}$ A similar approach could be used for a speech offence that criminalized the wilful promotion and advocacy of a terrorist activity. An alternative demanding fault requirement would be to require that the accused act for the purpose of enhancing the ability of a terrorist group to facilitate or carry out a terrorist activity. ${ }^{116}$ Such extraordinarily high subjective fault

2001 SCC 2 at para 56.

Criminal Code, supra note 5, s 83.01(1.1).

Ibid, s 83.01(b).

$R v$ Buzzanga (1979), 25 OR (2d) 705 (CA).

For an exploration of the importance but comparative rarity of such a purpose requirement, see Kent Roach, "Terrorism" in Markus D Dubber \& Tatjana Hörnle, eds, The Oxford Handbook of Criminal Law (Oxford: Oxford University Press, 2014) 812. 
requirements would ensure that an accused is not convicted simply on the basis of recklessness or awareness of the possibility that someone may engage in terrorist activity as a result of the impugned speech.

The requirements of wilful promotion or proof of a purpose to facilitate terrorism and the exemption in section 83.01(1.1) might, however, not respond to Hamdan's arguments that he was engaging in legitimate religious and political debate and trying to point out what he believed was the error of Canadian policies. If the hate propaganda model was followed, it would be advisable to include something akin to the protections for fundamental freedoms found in section 319(3) of the Criminal Code. They provide that no person shall be convicted:

(a) if he establishes that the statements communicated were true;

(b) if, in good faith, the person expressed or attempted to establish by an argument an opinion on a religious subject or an opinion based on a belief in a religious text;

(c) if the statements were relevant to any subject of public interest, the discussion of which was for the public benefit, and if on reasonable grounds he believed them to be true; or

(d) if, in good faith, he intended to point out, for the purpose of removal, matters producing or tending to produce feelings of hatred toward an identifiable group in Canada. ${ }^{117}$

The addition of such defences to a terrorist speech offence would clearly signal an attempt by Parliament to justify reasonable limits on freedom of expression.

At the same time, replicating the defences in section 319(3) would require someone like Hamdan to establish on a balance of probabilities that they had a legitimate purpose for what they said. The reverse onus on the defence would violate the presumption of innocence. Following the Keegstra majority, however, this Charter violation could be justified as responsive to the inherent harm and risk of speech that wilfully or intentionally promotes or advocates the commission of a terrorist activity. Moreover, the accused would be in a good position to establish defences based on his or her own good faith and belief in the truthfulness of the statements. That said, there is still the danger stressed by Justice McLachlin (as she then was) in her Keegstra dissent that it is unfair to require the accused to prove the truth or the public benefit of their speech and that a trial on such issues may only give the accused a more visible political platform. ${ }^{118}$ Clearly any terrorist speech provision will be risky in terms of whether the Crown will obtain a conviction, but also in terms of the social effects of the trial on a perhaps polarized public.

\section{THE NEED FOR STRONGER AND BROADER INTERNET TAKE-DOWNS}

The Othman Hamdan case study demonstrates how social media companies such as Facebook act as front-line censors of terrorist propaganda. Nevertheless, there are strong 
arguments that such acts of censorship should be regulated and guided by public powers that are subject to the Charter and other public law restraints on limitations of fundamental freedoms. The alternative is to rely on the private proprietary interests that the relevant companies have in their algorithms and machine-based learning that detect risky speech as augmented by the humans that they employ to decide what material to take down. ${ }^{119}$ Such a deregulated approach would depend only on consumer pressure and moral suasion to determine the censorship policies that will govern the Internet.

Although many were critical of the Bill C-51 offence of knowingly promoting or advocating terrorism offences in general, there was much less criticism of its related provisions in sections 83.222 and 83.223 of the Criminal Code to provide for seizure and deletion from computer systems of terrorist propaganda defined as material "that advocates or promotes the commission of terrorism offences in general ... or counsels the commission of a terrorism offence." ${ }^{120}$ Craig Forcese and I, while extremely critical of the Bill C-51 promotion and advocacy of "terrorism offences in general" offence, even recommended that the court-ordered deletion powers in Bill C-51 be expanded to include material that instructs the commission of terrorism offences. ${ }^{121}$ These deletion provisions are patterned on similar provisions in the Criminal Code in sections 320 and 320.1 that allow for the seizure and court-ordered deletion of hate propaganda if it is established on a balance of probabilities that the material advocates or promotes genocide or constitutes a hate propaganda offence.

Regardless of whether Parliament selected the decriminalization route or one that prohibited the promotion or advocacy of terrorist activity, there is a strong case that the court-ordered deletion of terrorist propaganda provisions originally placed in Bill C-51 should be strengthened to include material that not only counsels the commission of a terrorism offence but not any particular terrorism offence ${ }^{122}$ but also material that promotes and advocates terrorist activities and provides information about how to commit a terrorism offence. ${ }^{123}$ Bill C-59 may severely restrict the ability of courts to order the deletion of terrorist material under section 83.222 by requiring that such material "counsels the commission of a terrorism offence" $" 124$ without even the admittedly unclear expansion of the section 83.221 speech offence that counselling need not identify a specific terrorism offence.

The Department of Justice's Charter Statement on Bill C-59 justified reducing the definition of terrorist propaganda on the basis that counselling was less of a vague term and that most of the material that would be deleted would fall under the exception for threats of

119 Large companies have agreed to use enhanced technology, user reporting, and transparency reports to implement the Christchurch Call (Microsoft, Twitter, Facebook, Google \& Amazon, "Joint Statement in Support of Christchurch Call," online: <fbnewsroomus.files.wordpress.com/2019/05/christchurchjoint-statement-and-commitment-.pdf $>$ ). Smaller companies are, however, often associated with extremist content including content on both the far right and inspired by ISIL. Anti-terrorism Act, 2015, supra note 5, s 16.

Forcese \& Roach, "Terrorist Babble," supra note 15 at 79.

National Security Act, 2017, supra note 7, s 144, defining "terrorist propaganda" under section 83.222(8) of the Criminal Code.

123 For criticisms that Bill C-59 will weaken take-down powers by limiting the definition of "terrorist propaganda" to material that counsels the commission of a terrorism offence, see Shimon Fogel, "Ottawa Can Do More to Protect Us from Hate Crimes," The Globe and Mail (4 December 2018) A13. 
violence. ${ }^{125}$ But such a justification, however, treats the deletion procedure as if it was the equivalent of a criminal offence even though it does not result in a criminal conviction: it only requires proof on a balance of probabilities and does not require proof of criminal fault. Although they are included in the Criminal Code, the in rem remedies contained in section 83.222 of the Criminal Code are fundamentally different from criminal offences.

There has been only one reported case of a proceeding for court-ordered deletion of terrorist propaganda under Bill C-51, and its outcome remains unclear. ${ }^{126}$ Private efforts at deletion are likely to continue to dwarf any public process of deletion. At the same time, the deletion procedures in the Criminal Code could provide an example of a rights-compliant and procedurally fair process of deletion that some in the private sector might emulate. It would also allow the government to seek judicially approved and ordered deletion of the type of offensive material that Hamdan placed on the Internet without either having to establish his guilt beyond a reasonable doubt or running the risk of making him something of a free speech or free religion martyr. It would allow for public exposure and disapproval of terrorist propaganda without all the demands and risks of criminal prosecution. As the Hamdan case study indicates, this includes the risk of making the person prosecuted and detained more dangerous. That said, it must be recognized that private companies will be able to detect and remove material from the Internet more quickly than any public process and especially one that requires prior judicial approval.

\section{CONCLUSION}

Bill C-59's new terrorism speech offence makes it an offence to counsel "another person to commit a terrorism offence without identifying a specific terrorism offence." 127 This new offence may pull off the difficult and dubious trick of being both unable to respond effectively to speech advocating terrorism, while still being constitutionally suspect in its refusal to specify exactly what speech is prohibited. The new Bill C-59 offence may be a compromise, but one that should please no one because it continues to contain a vague offence targeting speech, but one that may be impossible to prosecute should courts continue to interpret the act and fault requirements of counselling in the restrictive manner that occurred in Hamdan. ${ }^{128}$

Replacing "terrorism offences in general" with an undefined and incoherent reference to counselling "terrorism offences without identifying a specific terrorism offence" may amount to a distinction from the previous offence without a difference. If interpreted to require some actual terrorism offence to be counselled, the provision may fail to capture the incitement of

125 The statement provided:

[S]ince the definition of "terrorist propaganda" will be restricted to writings, representations or signs that counsel the commission of a terrorism offence, the material to which the provision would apply can, in many cases, be considered as falling within the violence exception and so outside the otherwise broad protection for freedom of expression provided by section 2(b) of the Charter. For any other statements that may be caught by the offence, the prohibition may be viewed as a proportional response to the objective of addressing the threat posed by the terrorism offences.

(Department of Justice, "Charter Statement - Bill C-59: An Act respecting national security matters," (Ottawa: DOJ, 2017) at 21, online: <www.justice.gc.ca/eng/csj-sjc/pl/charter-charte/ns-sn.html >).

The nature of the material and the target of the proceeding remains under court seal: Colin Freeze "Ottawa Uses Expanded Powers to Target Terrorist Web Content," The Globe and Mail (17 September 2018) A1.

National Security Act, 2017, supra note 7, s 143, amending section 83.221 of the Criminal Code. See supra note 11. 
unspecified acts of terrorism such as Hamdan's retweeting of calls for "lone wolves to activate."

Alternatively, if no codified terrorism offence must be counselled under the new version of section 83.221 of the Criminal Code, the new offence, like the Bill C-51 offence of promotion or advocacy of "terrorism offences in general" will be vague, overbroad, and as such vulnerable to Charter challenge.

Should a terrorism speech offence be deemed necessary, it should differ significantly from both the Bill C-51 and C-59 versions. Given the restrictive interpretation of counselling in Hamdan, it should follow Bill C-51 and apply the broader concept of promotion or advocacy. In order to avoid Charter problems, however, such a broadly defined prohibited act should include protections for free speech and religion similar to those provided in section 319(3) of the Criminal Code. It would have been better for any speech offence to refer to "terrorist activities" as defined in section 83.01(b) of the Criminal Code: a phrase that has already been held to impose reasonable restrictions on fundamental freedoms. ${ }^{129}$

As Hamdan well demonstrates, however, any prosecution of terrorist speech will remain risky and could be counterproductive. This means that the calls that many made during the long debate on Bill C-59 simply to repeal Bill C-51's terrorist speech offence remain defensible. Such a repeal need not produce a sanctuary for all terrorist-related speech. For example, other existing offences such as uttering threats could be used and arguably should have been used in Hamdan. It would still be possible to charge people with counselling specific terrorism offences and other offences such as counselling murder.

Except for two pre-arrest interviews by four different RCMP constables, CVE was never really attempted in the Hamdan case. The CVE option is risky given that the knowledge base about what works is not robust. Hamdan did not change his Internet behaviour after two meetings with the RCMP, including one where they purchased him a muffin and coffee at Tim Horton's. But we will never know whether civilian and civil society-led CVE could have channelled Hamdan's beliefs and critique in a better direction. Alas, CVE remains nascent in Canada. ${ }^{130}$ It has traditionally been led by the RCMP who, as Hamdan reveals, have obligations to enforce the criminal law including speech-based offences. The ultimate denouement of the Hamdan case should also satisfy few because it suggests that Canada has fallen back to old bad habits of using immigration law as anti-terrorism law. In cases involving citizens, such shortcuts will not be available.

What we do know is that Hamdan was acquitted of various counselling offences and may well have been acquitted if charged under the new counselling-based offence in Bill C-59. The meaning of Hamdan's acquittal was undermined by his subsequent immigration detention and deportation order to Jordan. Hamdan's treatment by the Canadian state has by all accounts made him more dangerous. Canada seems prepared to export this problem to Jordan, but it is unclear whether doing so will make Canada complicit with mistreatment that Hamdan might receive in Jordan. Although Facebook removed many of Hamdan's posts, the state could probably not obtain court-ordered deletion under Bill C-59 given findings that

\footnotetext{
129 See Khawaja, supra note 13.

130 Kent Roach, "The Migration and Evolution of Programs to Counter Violent Extremism" (2018) 68:4 UTLJ 588.
} 
they, in almost every case, did not counsel an offence. Social media companies emerge from this case study as more effective, important, and less restrained front-line censors than the state.

Hamdan might have been more likely to have been convicted under the Bill C-51 offence of promoting or advocating terrorism offences in general, but that offence might well have been struck down under the Charter as an overbroad violation of freedom of expression. In any event, Canada under Bill C-59 seems unprepared to deal with the sort of Internet speech used by Othman Hamdan or those on the far right who make generalized and unspecific calls for violence.

This article has suggested that such speech can be prosecuted in criminal courts provided sufficient protections and defences are provided for free speech. But that is not the only alternative. Civilian-led and evidence-based CVE programs are another way to respond to speech that engages in violent extremism. Unfortunately, Canada has neither of these two defensible and coherent options in place to respond to such alarming speech. Hence, speech like Hamdan's will in the future continue to be regulated by the changing take-down practices of social media companies and other ad hoc measures such as the use of immigration law against Hamdan. 
[this page is intentionally blank] 